\title{
Managing People and Landscapes: IUCN's Protected Area Categories
}

\author{
Pris Weeks ${ }^{1}$ and Shalina Mehta ${ }^{2}$ \\ 1. Houston Advance Research Centre, Houston, USA \\ E-mail: weeks@cl.uh.edu \\ 2. Department of Anthropology, Punjab University, Chandigarh, India \\ E-mail: shalinamehta@rediffmail.com
}

KEYWORDS Selection. Management. Protected Areas. Biological Goals. Conservation. Self-determination

\begin{abstract}
The International Union for the Conversation of Nature (IUCN) is the lead organization in the selection, establishment and management of protected areas. In order to accomplish its advisory management function, IUCN maintains a worldwide list of protected areas. Each protected area on the list is placed into one of 6 categories based on its management goals. In addition to the identification of biological goals, a protected area's classification identifies what human activities are allowed in that protected area. The classification scheme thus organizes the lives of people living in and around protected areas and has material consequences for local communities that can be at odds with the principle of self-determination. IUCN is placed in a difficult position in that it promotes both self-determination of local peoples and conservation. It tries to bring these two goals into harmony in its approach to protected area classification. After briefly tracing the evolution of IUCN's position on people and protected areas, we will describe the classification system, and then turn to an examination of the ways that local peoples are managed. We conclude with a discussion of the difficult task IUCN faces in trying to rectify peoples' rogjts with conservation needs.
\end{abstract}

"The vine was now bundled, and he took off again. In the left pocket of his shirt he could feel the identify card they had given him that morning. There was a picture on it, it had come out dark and he looked rather sluggish. But he was now a legal vine collector." (BorriniFeyerabend, 1996: vi).

\section{INTRODUCTION}

Protected areas such as national parks and wildlife sanctuaries are physically shared by ecologically important flora and fauna, tourists, government officals, scientists and communities living in and around them. Diverse and competing meaning have been attached to landscapes as they have come under the control of different social groups from indigenous peoples to colonizers to post-colonial governments and new migrants from the cities. The conferment of protected area status imposes yet another set of meaning on these lands and creates a new set of justifications for altering the material reality of local people. This paper discusses the relationship between the way in which protected areas are conceptualized, focusing on the methods used to classify and manage these lands and the management of the human communities dependent on them.

In his 1998 book, Seeing Like a State, James Scott discusses governmental attempts to organize lands and people. He analyzes an array of state imposed schemes from the assignation of last names and the institution of common weights and measures to the use of cadastral surveys and the institution of scientific forestry and agriculture. Tying these seemingly disparate actions together is a drive toward organization, simplification and progress. Order is imposed on landscapes and people who appear disordered to outsiders, thus facilitating the governance of both. People with last names can be easily identified, counted and conscripted. Common measures, last names, and surveys facilitate taxation. Forest monoculture and uniform agricultural plots facilitate state control of production and harvest, etc. Brosius uses the current conservation practice (1999: 50). It is a term that is particularly apt when describring. The World Conservation Union - International Union for the Conservation of Nature (IUCN) categorization of protected areas.

IUCN categories organize the lives of people living in and around protected areas. A protected area's classification dictates what human activities are allowed in that area, leading to management of local communities. The underlying logic of classification-control over people and territory-can have material consequences for local communities and can be at odds with the principle of self-determination. The conflicts that emanate form this external control are 
located in people's perception of their rights and control over resources. In this paper we will briefly trace the evolution of IUCN's position on people and protected areas, we will describe the classification system, and then turn to an examination of the ways that local peoples are managed. We conclude with a discussion of the difficult task IUCN faces trying to rectify people's rights with conservation needs. Our discussion of IUCN is based on a review of: the meeting summaries and resolution from the IUCN General Assemblies and current IUCN publications relating to local communities and protected areas.

\section{THE WORLD CONVERSATION UNION-IUCN AND PROTECTED AREAS}

IUCN is a confederation of about 1300 government and non-governmental organizations working in over 160 countries. Members include World Wide Fund for Nature (World Wildlife Fund in the US), the World Bank, the United Nations, the Organization for Economic Cooperation and Development and US Agency for International Development. IUCN serves as a broker between national governments, local communities and the international environmental community by helping to draft environmental legislation and national conservation plans, supervising national and local level projects and designing environmental education compaigns. It is the lead organization in the selection, establishment and management of protected areas. IUCN defines a protected area as "an area of land and/or sea especially dedicated to the protection and maintenance of biological diversity, and of natural and associated cultural resources, and managed through legal or other effective means" (IUCN, 1996: 2).

The United Nations directed IUCN to compile a worldwide list of protected areas in the early 1960s and the first United Nations List of National Parks and Equivalent Reserves was published in 1967. Not only were protected areas listed, they were assigned to one of three categories: scientific reserve, national park or national monument. One goal of classification is to encourage countries to preserve lands in each category. Additionally, classification should illustrate "the potential range of management "tools"" as well as "provide the framework for comparing protected area systems..." (McNeely et al., 1994: 7).

Almost from its inception, IUCN has expressed ambivalence about the people living in and around protected areas. Before turning to how this ambivalence is expressed in its current protected area classification scheme, it might be helpful to describe, in a general way, IUCN's changing views on people and protected area. IUPN, the International Union for the Preservation of Nature, was formed in 1948, shortly after the end of WWII. Colonies were changing hands, some becoming independent. International cooperation was seen by many as key to development, not to mention prevention of another world war. The United Nations was beginning to broaden its scope of interest. Natural scientist and evolutionary theorist Julian Huxley was appointed director of the newly formed United Nations Educational, Scientific and Cultural Organization (UNESCO) in 1945. Searching for a way to involve UNESCO in nature preservation, Huxley and a group of like minded colleagues proposed the creation of IUPN, which was to have strong ties to UNESCO (Huxley, 1973).

The original name was the International Union for the Preservation of Nature and it was staffed by natural scientists from Europe and the USA, several of whom were close friends of Huxley. The early overwhelming European Presence in IUPN made the organization vulnerable to accusations of colonialism. IUPN's Executive Board was controlled by Europeans from 194859 and there were few delegates from the South to its international meetings until the late 1960s despite the focus on Southern issues (Holdgate, 1999). The relative lack of participation from former colonies seemed to give credence to the charges of colonialism.

IUPN responded to such criticism by recognizing, at least formally, that the concept of preservation was problematic. It acknowledged that preservationist policies advocating the maintenance of pristine landscapes dedicated to scientific, aesthetic and educational purposes were offensive to newly decolonized governments dependent on natural resources for local communities and foreign exchange. In 1956, the IUPN Directorate changed the name from IUPN to IUCN-replacing the word preservation with conservation, The intention was to signal the organization's commitment to post-colonial development and to convey the message that it 
did not overly privilege nature over people.

More than a name change was needed, however, to clarify the organization's position on people and protected areas. The name change itself caused a heated debate between conservationists and preservationists within the organization, forming the basis for a lingering organizational ambivalence about people and protected areas. For example, in 1969, the General Assembly recommended that occupation and exploitation be eliminated from national parks. National parks were envisioned as places where "visitors are allowed to enter, under special conditions, for inspirational, educative and cultural and recreational purposes" (IUCN, 1969: 1). The Assembly also recommended eliminating "as soon as possible exploitation or occupation in the whole area (ibid:1)". Thus, land that had been grazed, burned, farmed, hunted on and gathered from became naturalized in the process of removing the grazers, burners, etc. The Yellowstone model (named after the park in the United Stated) which removed humans from protected areas, was favored among many Americans in IUCN who envisioned it as a worldwide model (Holdgate, 1999). In the 1960's other countries adopted the Yellowstone model in earnest, defining a national park as being uninhabited (McNeely, 1994).

Only six years after recommending the removal of resident peoples from national parks, IUCN directly confronted the disconnect between the perception that national parks should be uninhabited and the reality that on a global level, most protected areas (of all categories) are either inhabited or have nearby communities dependent on their resources. In a resolution entitled "Protection of Indigenous Ways of Life," IUCN officially revised its previous position by recommending that governments devise ways so "that indigenous people can bring lands into conservation areas without relinquishing their ownership, use or tenure rights" (IUCN, 1975: 2). The General Assembly specifically stated that people should not be routinely relocated and went so far as to recommend that local people be consulted in the designation of a protected area.

The Fourth World Congress on National Parks and Protected Areas was held in Caracas in 1992. The theme was "Parks for Life," and the conference focused on the services-both biological and human-that protected areas provide. It was at the meeting that IUCN formally abandoned the Yellowstone model and explicitly recognized that areas previously believed to be pristine, were not (Holdgate, 1999). Furthermore, in the introduction to the conference proceedings, the words wilderness and pristine are in quotes. The authors confront older views of un-peopled nature when they state, "Experience quickly showed, however, that most parts of the world already had people living there, or at least had people with legitimate historical claims to the land" (McNeely et al., 1994: 5)

Statements acknowledge historic human habitation in and around protected areas force conservationists to deal with the issue of human rights in addition to conservation. IUCN undertakes this in a 1998 position paper entitled "Principles and Guidelines on Indigenous/ Traditional Peoples and Protected Areas" that it co-authored with WWF and the World Commission on Protected Areas. This document states principles of relationship between protected areas and local peoples. WWF and IUCN specifically state "that the territorial and resource rights of indigenous and other traditional peoples inhabiting protected areas must be respected" (WWF, IUCN \& WCPA, 1998: 2).

\section{PROTECTED AREA CATEGORIES}

Despite historical attempts to balance the rights of local peoples and conservation goals, IUCN's current classification system for protected areas manifests the same tensions that have plagyed the organization since its inception. We want to turn to some of the language IUCN uses in its classification system to highlight the tension between the conception of protected areas as a site of scientific, touristic, and above all, ecological processes, and the idea that they can also be home to human communities.

Originally there were three protected area categories: scientific reserves, national parks and national monuments. In line with the thinking of the time, these landscapes were envisioned as un-peopled. Classification was revised in 1978 to more accurately reflect both the variety of protected areas and the significant human habitation that occurred in many protected areas. The 1978 system described 8 categories of reserves, the last 4 specifically mentioned human use or habitation. Category 7 was actually called Natural Biotic Area/ Anthropological Reserve. 
The classification system was revised again in conjunction with the 1992 Fourth World Congress on Protected Areas and currently is based on 6 categories.

IUCN judges its success in the establishment of protected areas along two axes. One, it encourages countries to have all 6 categories of protected areas. Two, it strives to save ecologically representative tracts. To help accomplish this, IUCN established the Protected Areas Data Unit and helped found, along with WWF and the United Nations Environment Program, the World Conservation Monitoring Center (WCMC). The latter has fully described 5000 protected areas. The global list includes over 8500 sites from 120 countries (Caracas Action Plan, 1992). Using Geographical Information Systems technology, WCMC and IUCN map the boundaries of existing protected areas, and identify bio-regions in which new protected areas might be needed. IUCN has organized the earth into 13 terrestrial and 18 marine regions (IUCN, 1996). For example, North Africa and the Middle East would constitute one terrestrial region, Europe would be another, East Asia another etc. The Northwest Atlantic, Northeast Atlantic, Northwest Indian Ocean are examples of marine regions.

IUCN classifies protected areas into categories according to the natural and/or cultural objectives that the areas is supposed to be. Category I, Strict Nature Reserves/ Wilderness Areas, is managed for wilderness protection and/ or scientific study. Category II, National Parks, is managed in a way that supports both ecosystem functions and recreation. Category III, Natural Monuments, conserves specific natural features, Category IV, Habitate /Species Management Areas, is managed for conservation but requires an interventionist type of management. Category $\mathrm{V}$, protected Landscapes and Seascapes, is managed for conservation and recreation. Category VI, Managed Resource Protected Areas, is managed for the sustainable use of natural ecosystems.

Nationally managed protected areas are assigned to the appropriate IUCN category according to their legally mandated management objectives but not all protected areas in the world are included on the list. Many are too small. Sweden, for example, has preserves total in 430,000 hectares that are not included (McNeely et al., 1994). In addition, the IUCN classification system does not 'map onto' national categories. Australia has a total of 34 terrestrial and 12 marine categories (Bridewater and Shaughnesy, 1994: 220).

Several sets of tensions are embedded in the current classification scheme: between conservation and preservation, between a domesticated landscape and a wild landscape, between national control and local control, and between conservation goals and traditional rights. IUCN faces a daunting challenge to bridge this conceptual, one might even say ideological, divide and in trying to do so as expressed a kind of conceptual ambiguity about people in protected areas. This is manifested in IUCN's definition of natural areas.

Natural areas are the keystones of the protected area classification system and references to them are found in almost all of the categories of protected areas. Even category 6 protected areas, which are primarily devoted to extraction, must consist of $2 / 3$ natural areas (IUCN 1996). The IUCN definition of natural areas is:

Ecosystems where since the industrial revolution (1750) human impact (a) has been no greater than that of any other native species, and (b) has not affected the ecosystem's structure. Climate change is excluded in this definition. (IUCN, 1994:10)

Note that human impact should be no greater than that of any other native species. Although the average layman might take this statement to preclude human habitation, ecologists recognize that many native non-human species alter their habitat for example the 'beaver meadows' favoured by New Englave colonists (Merchant, 1989). These meadows formed where beaver dams slowed water flow and trapped sediments to such an extent that a large muck was created and colonized by grasses.

It is clear that IUCN struggled with how to define natural. IUCN wants to protect the rights of people living in protected areas, but not to the extent that they have the right to alter the landscape to such a degree that it loses those very qualities that brought it into protected status. Using the industrial revolution as a historical reference is an attempt to save traditional productive systems.

At first glance, this seems like a good compromise. Humans are animals and as such are part of an ecosystem. But the IUCN definition 
of a natural area conceptualizes particulars groups of human beings - indigenous peoples on the same level as non-human animals in a way the rest of use are not conceptualized. Indigenous people leading traditional lifestyles are portrayed as being more 'natural' than nonindigenous people. Although the word primitive is currently out of vogue, remnants of the concepts persist and are manifested in this IUCN definition of natural. As Conklin and Grahm point out, such representations of indigenous peoples define them "in ways that contradict the realities of many native people's lives" (1995: 703).

Such representations also force resident peoples to collude in their own stereotyping, however romantic, in order to forge alliances with environmental groups (see for example Turner, 2000; Brosius, 1997, 1999; Conklin and Gram, 1997). Furthermore, their production strategies are restricted to levels of ecological change found in the animal world. IUCN's definition of 'natural' freezes resident peoples in time, locking them into traditional technologies.

It is not our intention to enter the debate about indigenous peoples and their relation to nature. We refer readers to the citations immediately above plus the discussion between Schwartzman et. al. and their respondents in the October 2000 edition of Conservation Biology for an overview of this debate. Our purpose in this paper is to highlight the potential conflict between selfdetermination of native peoples and conservation (as defined by ecological science) of protected areas.

The question of self-determination is an issue that is separate from a group's ecological sensibility (unless one ascribes to the view that only social groups that share one's own view of conservation are entitled to self determination). IUCN is by no means the only conservation organization trying to deal with this issue. We consider it the leader in this area by virtue of its ability to assign protected areas to a particular protected area category. Despite the fact that governments have their own categories, IUCN categories serve as a guide for management for national and regional governments.

\section{THE CATEGORIES}

Below we briefly describe the management functions and definitions of 4 of the 6 categories. these categories were chosen because they are the most illustrative of the conflict between conservation and human rights goals embedded in the classification system. Category I contain two types of landscape use: strict nature reserves and wilderness areas. A Strickt Nature Reserve is an "Area of land and/or sea possessing some outstanding or representative ecosystems, geological or physiological features and/or species, available primarily for scientific research and/or environmental monitoring." (IUCN, 1994: 17) Strict Nature Reserves are managed to preserve ecosystems, eco-processes, genetic resources and geological features. The appropriate human uses are research and monitoring.

A wilderness area is defined as; "Large area of unmodified or slightly modified land, and/or sea, retaining its natural character and influence, without permanent or significant habitation, which is protected and managed so as to preserve its natural condition." (IUCN, 1994:18)

\section{Wilderness Area should be Managed to}

- ensure that future generations have the opportunity to experience understanding and enjoyment of areas that have been largely undisturbed by human action over a long period of time;

- maintain the essential natural attributes and qualities of the environment over the long term;

- provide for public access at levels and of a type which will serve best the physical and spiritual well-being of visitors and maintain the wilderness qualities of the area for present and future generations; and

- enable indigenous human communities living at low density and in balance with the available resources to maintain the lifestyle. (ibid).

Note that wilderness is unmodified or slightly modified. It should "be governed primarily by the forces of nature, with human disturbance substantially absent.." (ibid). It is 'natural,' having no significant or permanent habitation. However, one management objective is to enable indigenous communities living under particular conditions to preserve their lifestyle in a wilderness area.

IUCN obviously recognizes that indigenous 
people have historically altered landscapes once considered to be pristine and without human influence - hence the reference in the definition of natural area to the industrial revolution. For example, there is archeological evidence that prehistoric Amazonian Indians altered soils and re-designed is acceptable under IUCN's definition of natural because it is pre-modern. It does not affect the ecosystem structure that we know today.

The goal of enabling indigenous communities to maintain their lifestyle is a laudable one, but one that assumes that indigenous peoples want to maintain all aspects - productive as well as cultural - of their traditional lifestyle. Prohibiting non-traditional practices that would upset the human/environment balance locks local communities into a time warp that may or may not be in keeping with their desires. Conklin and Graham discuss the problems that such a noble savage ethic poses for indigenous people. They rightly note: "Environmentalists' primary goal is to promote sustainable systems of natural resources management. Indigenous peoples resources." (Conklin and Graham, 1995: 703) The fact that both the Amazonian Kayapo and Guajaro Indians have tried to negotiate lumber contracts much like their mainstream counterparts belies the notion that maintenance of cultural traditions is necessarily linked to maintenance of traditional production systems (Conklin and Graham, 1995).

We find similar incidents here in India. In the state of Meghalya, local communities protested the Supreme Court's decision to ban logging. They, shifted from planting trees to clearing land for agriculture - an activity that was not under the purview of the state authorities.

In such cases, self-determination and indigenous rights are to be based on the assumption that living in their traditional homelands after they are declared a protected area is a privilege, with conditions, not a right.

Category II refers to national parks. IUCN defines a national parks as:

"Natural area of land and/or sea, designated to (a) protect the ecological integrity of one or more ecosystems for present and future generations, (b) exclude exploitation or occupation inimical to the purposes of designation of the area and (c) provide a foundation for spiritual, scientific, educational, recreational and visitor opportunities, all of which must be environmentally and culturally compatible." (IUCN, 1994: 19)

\section{Objectives of Management}

- to protect natural and scenic areas of national and international significance for spiritual, scientific, educational, recreational or tourist purposes;

- to perpetuate, in as natural a state as possible, representative examples of physiographic regions, biotic communities, genetic resources, and species, to provide ecological stability and diversity;

- to manage visitor use for inspirational, educational, cultural and recreational purposes at a level which will maintain the area in a natural or near natural state;

- to eliminate and thereafter prevent exploitation or occupation inimical to the purposes of designation;

- to maintain respect for the ecological, geomorphologica, sacred o aesthetic attributes which warranted designation; and

- to take into account the needs of indigenous people, including subsistence resource use, in so far as these will not adversely affect the other objectives of management. (ibid: 19)

National parks are natural areas that provide transcendental, adventure and educational experiences. One management goal, however, is to take into account the needs of indigenous people. In this way, parks serve multiple constituencies that have sometimes been at loggerheads. Uluru, previously known as Ayers Rock, provides a good example of potential conflicts between indigenous peoples and tourists (Donnan, 2000). This sacred site was returned to its original owners, the Anangu, in 1985. The Australian government currently leases the area as a national park which receives more than 400,000 visitors a year and brings in $\$ 4.5$ million australian dollars. The Anagu request that visitors refrain from climbing Uluru due to its sacred status. Scaling the rock is a long-standing tradition among majority Australians. Many visit the area primarily to do so. Tourist operators are pressing for the rock to remain open to climbers. Potential conflicts such as the Uluru case area embedded in the management objectives IUCN has set for national parks - i.e to satisfy both 'outsider' and 'insider' needs.

A similar episode is reported from the 
National Park, Nagarhole in Karnataka (Muzaffar, 1996). When the Tribal groups living in the area found out that the mookal Jungle resort was to be rented out to Taj group of hotels for Rs. 1.25 lakh per annum, they resisted, claiming that eco-tourism interferes with long established cultural tradition. According to Muzaffar, tranference of tribal peoples' land rights to outsiders has resulted in the conversion of eco-tourism into eco-terrorism.

Category IV, habitat/Species Management Areas, is actively managed for conservation. a management area is defined as:

- Area of land and/ or sea subject to active intervention for management purposes so as to ensure the maintenance of habitats and/or to meet the requirements of specific species. (IUCN, 1994: 21).

\section{Objectives of Management}

- to secure and maintain the habitat conditions necessary to protect significant species, groups of species, biotic communities or physical features of the environment where these require specific human manipulation for optimum management;

- to facilitate scientific research and environmental monitoring as primary activities associated with sustainable resource management;

- to develop limited areas for public education and appreciation of the characteristics of the habitat concerned and of the work of wildlife management;

- to eliminate and thereafter prevent exploitation or occupation inimical to the purposes of designation; and

- to deliver such benefits to people living within the designated area as are consistent with the other objectives of management. (ibid: 21).

Although these areas are actively manipulated to maintain habitats or species, they also should deliver benefits to people living in the area. Unfortunately, the needs of certain species and the needs of people can be in opposition (Kothari, 1991; Dang, 1991). Tigers attack livestock, and sometimes, people. Elephants trample fields and tear up forests. Browsers, such as deer, can destroy crops. Once again, the management goals contain the seeds of conflict between resident peoples and conservation.

Category VI consists of Managed Resource
Protected Areas, defined as: “area(s) containing predominantly unmodified natural systems managed to ensure long-term protection and maintenance of biological diversity, while providing at the same time a sustainable flow of natural products and services to meet community needs." (IUCN, 194: 23)

\section{Objectives of Management}

- to protect and maintain the biological diversity and other natural values of the area in the long term;

- to promote sound management practices for sustainable production purposes;

- to protect the natural resource base from being alienated for other land-use purposes that would be deterimental to the area's biological diversity; and

- to contribute to regional and national development. (ibid: 23).

The area should be at least two-thirds in a natural condition before it can be classified as a managed resource protected area. Although the area may also contain limited areas of modified ecosystems, large commercial plantations would not be appropriate (ibid: 23). The Managed Resource Protected Area is IUCN's newest category and was developed at the request of its Third World members who desired explicit recognition that protected areas could be managed for sustainable production.

Category VI protected areas are managed for both biological diversity and the production of goods to meet community needs. Note, however, that at least $2 / 3$ of these areas should be natural - i.e. people cannot impact the area any more than any other native species. And, as in all protected areas, human activities must always be consistent with the scientific management and conservation objectives.

\section{MANAGING LOCAL COMMUNITIES}

IUCN's classification system is grounded in scientific understanding of natural processes/ phenomena such as ecosystem functions, genetic diversity, and species diversity. All protected areas should preserve natural processes. To accomplish this, people in protected areas must be managed. Their activities are curtailed in order to maintain natural landscapes. In some of its other (non-classification) literature, IUCN 
uses the term 'rights' to describe people's traditional relationship to lands that now fall under protected area status (WWF, IUCN \& WCMC, 1998). These rights, however, are bounded by scientifically derived conservation goals. This has resulted in the replacement of traditional, locally constructed and specific systems of both production and usufruct rights.

Local people now content with state issued permits for, and quotas on, needed resources such as grass, nuts etc., as well as leases, concessions, certificates and ID cards necessary for entering particular areas. Their productive activities are reconfigured to comply with management goals. Kanha National Park offers a good example of government policy that reconfigures resident people's productive strategies.

The Indian author of this paper has worked in the Kanha region among the Gond and the Baiga tribals since 1988-89. The Indira Van Gram village was one of the first to be relocated out of the park onto to land that was not owned by either the Forest or Revenue Departments. Consequently neither of these government entities felt responsible for the villagers, arguing that the village was outside of their administrative zone.

The people inhabiting these villages did not have access to safe drinking water or other amenities. Nor did they have means to level the rough lands that were allotted to them. They were neither allowed to collect fodder nor minor forest produce from land that was once their home.

Things have changed since they were first relocated and physical dislocation has been replaced by restrictions on productive activities. The current mode of dealing with villages in and around the park is through buffer zones located at the outskirts of the park. These buffer zones serve as a transition zones between core, highly protected areas of the park and areas with human habitation and production. Villages located in the buffer zones benefit from the resources available in the region. They have restricted license to collect firewood, minor forest produce and graze their cattle in these buffer areas, allowing them access to these zones as these activities are carried out without disturbing the eco-system.

The Maldhari, living in and near the Gir protected area in Gujarat offer another example of the reconfiguration of production. The protected area encompasses both a national park and a sanctuary. The maldhari were pastoralists who raised buffalo and cattle for dairy products and manure-both of which they sold. Ecosystem competition with the rare Asiatic Lion (Panthera leo persica) led to their involuntary resettlement outside of the protected area by the Gujarat government. Between 1972 and 1986, about 60\% of Maldhari families were relocated out of the protected area (Choudhary, 2000). Conservation specialists blamed the Maldhari pastoral lifestyle and grazing practices (letting cattle wander) for the ecological degradation of Gir. The resettlement goal entailed a new lifestyle and pastoralists were transformed into agriculturists vis a vis a development project that provided plowed fields, house plots and common grazing lands (Choudhary, 2000; Narayan, 1996). Thus the entire lifestyle of the Maldhari was reconfigured to meet the management goals of the protected area.

IUCN has been struggling to rectify the seeming disparity between conservation goals and the rights of local communities, between 'top down management and complete local control. In 1996, the organization passed a resolution on something in-between-namely collaborative management. The resolution recognizes the needs of local communities and, considering their historical relationship to the area, gives them some voice in management. Joint Forest Management is an example.

IUCN envisions collaborative management as a stakeholder process (Borrini-Feyerabend, 1996; Lewis, 1996). This is a rationalized approach with a set of fairly distinct methodologies for getting input from relevant parties - i.e. stakeholders. IUCN defines stakeholders as "those individuals or groups who are directly involved in the conflict, or who may be affected by how the conflict is resolved" (Lewis, 1996: 9). The Caracas Action Plan suggests that protected area managers "Identify all the groups with a particular interest in protected areas and enable them to participate actively in the system planning process. Review the plan widely with all potential interest groups and agencies before final adoption and periodically thereafter" (IUCN \& CNPPA, 1992: 3).

The identification of all possible stakeholders, including research institutions, tourists and international conservation organizations like IUCN, formalizes and legitimizes what to villagers may seem like interference from 
outsiders. Furthermore, stakeholders having an 'interest' of 'stake' in the context of protected areas can include water and energy supply companies and the media. Villagers' status vis a 'vis the area is eroded from having rights to the land to having a stake in the land (i.e. from usufruct rights owner to stakeholder).

It also complicates negotiation. Before the advent of stakeholder groups, villagers primarily contended with the government in the form of local officials, sometimes with the aid of a mediating NGO. Under the stakeholders regime, they are one of several players. Although IUCN recognizes that some stakeholders have more rights than others, the stakeholder model itself and the processes negotiators are taught, are predicated on the assumption that the needs of all stakeholders should be met - i.e. the win-win model (Lewis, 1996). This dilutes the power of local communities who have devised their own methods of dealing with government managers.

In India, for example, a common and historically rooted strategy for dealing with rulers of all stripes is protest (Omvedt, 1993; Guha, 1989). In the course of our own field work in 1997, we found that violent protests and demonstrations at entry points to the Kanha National Park still occurred. This was symbolic of people's disenchantment with management strategies such as permits to enter the park, checkpoints etc. Protest is de-legitimated in formal, facilitated negotiations which are based on consensus building and non-confrontation (Poncelet, 2001).

IUCN does recognize that the stakeholder process is an introduced, rationalized method for gaining consensus (Lewis, 1996). It directs protected area managers to develop particular stakeholder efforts in concert with local custom, preferably building on existing institutions. In other words, it seeks to "tweak the rationalized method that solicits input from a variety of interests instead of adopting a more localized approach. More work is needed to asses the extent to which stakeholder processes displace less formal, more traditional ways of making decisions and handling conflict.

The threats to protected areas have been scientifically defined by conservationists in terms of ecosystems functions etc. The goal of working with villagers, as in any stakeholder process, is to be obtain "buy in" for the negotiated solutions. One must remember, however, that the ultimate goal - conservation - has already been set in the IUCN categories. Obtaining "buy in" in the conservation of protected areas translates into finding ways to sustain villagers while minimizing their impact on the protected area - the protected area and its classification being nonnegotiatible. Villagers area to be controlled albeit humanely. The new rationalized stakeholder process of communicating with local communities exapands the IUCN role from being a land manager to a people manager.

\section{DISCUSSION}

Despite attempts to include humans in protected areas, the "old" conceptual division between natural and cultural system in which natural systems are considered 'pristine' without human interference - still seems to underlie IUCN's classification system. IUCN first conceptually removes humans from nature in the Strict Nature Reserve model, (Category 1a) bringing them back into the picture in a series of discreet activities assigned to the various categories of preserves. The implication is that human activities, other than scientific study, impede 'natural' activities. Furthermore, the conservation of natural systems takes precedence over the conservation of cultural systems. Human goals and conservation goals are not conceptually integrated. Despite our understanding that these landscapes are peopled, natural landscapes are still seen as pristine only without human beings. Humans are allowed to live in protected areas only under certain conditions, and the primary IUCN goal is to protect landscapes.

The cognitive construction of protected areas manifested in IUCN's categories (and the management strategies arising from them) differs radically from that of the communities living in and around them. the assignation of activities appropriate to particular areas organizes local people's relationship to the landscape in new ways and fails to capture how particulars protected areas are traditionally used. For example, on India's Independence Day in 1996, one of the indigenous tribal groups located in the Nagarhole National Park area in Coorg district demanded 'freedom' and 'liberty' from rehabilitation, freedom from exploitation, freedom from eco-tourism perpetrated by the Indian State and western capitalism/World Bank' (Muzzafar, 1996). Similar sentiments have been 
expressed in other areas.

India has debated the relationship between local communities and protected areas since the 1800s. In 1878 Frederic Le Play challenged state monopoly over forest management and argued against re-location of local communities (1995: 2026). Nevertheless these issues remain unresolved and India continues to relocate unwilling villagers out of protected areas (The Hindu, 1998; interviews with forest officials, 1998). Despite IUCN's current position against relocation, IUCN classification of protected areas legitimates the Indian Government's actions by embedding them in ecological logic. Such logic can be seem in a recent World Bank funded project.

In 1996, the Word Bank launched a 70 million dollar biodiversity project in India (India Eco-development Project, 1996). In it, India is ecologically conceptualized as one of the 12 mega diversity countries of the world with 6070 percent of the earth's biodiversity. Seven protected areas, Buxa Tiger reserve in West Bengal, Palamu Tiger Reserve in Kerala, ranthombore Tiger Reserve in Rajasthan, Gir National Park in Karnataka and Nagarhole National Park in Karnataka are included in the project. in total it covers $6,714 \mathrm{~km}$. with a tribal population of 48,000 .

According to project planners, humans threaten the biodiversity in these protected areas through harvesting timber and non-timber forest produce, hunting, uncontrolled fires, conversion to agricultural lands, industrial and commercial development, high human population density and growth, high incidence of poverty and large number of livestock. People living in the core areas of these reserves will need to be relocated. Planners hope that this can be done on a voluntary basis as appropriate opportunities are created, but given past relocation efforts one wonders how successful voluntary relocation will be and what will happen if people do not want to leave the core areas?

The language IUCN uses to conceive of its protected areas categories reveals that it is having trouble synthesizing two movements; a conservation movement based on transcendental and scientific notions of nature and wilderness; and a human rights movement, based on the notion of equity and self determination. A human rights perspective, which grant the same rights of self determination to local peoples (i.e. the right to reject protected area status altogether), endangers the quality of landscapes according to IUCN criteria. In other words, some very critical habitat or species could be lost if local people are granted full rights to the areas they live in. It is hard to deny that granting Amazonian Indians, for example, the right to engage in large-scale logging could result in severe ecological degradation and perhaps even the extinction of endemic species. yet folding human rights under the umbrella of conservation seems to curtail rights of local people.

Our stress on the ways in which IUCN's protected area classification serves to control local communities is not meant to suggest that there is no need for protected areas. It would be impossible to deny the extent of ecological degradation facing the world today. Nor are we suggesting that IUCN does not have the best interest of local communities at heart. Unfortunately, as 40 years of poorly conceived development projects demonstrate, good intentions cannot shield us from unintended negative consequences.

\section{ACKNOWLEDGEMENTS}

The authors wish to thanks IUCN librarian Cecile Thierry for her help accessing materials in the IUCN library, Marianne Kermisch for help accessing WWF materials: and Jim Lester and Eric Poncelet for their comments. Support from NSF grant \#SBR 9601552 is also gratefully acknowledged.

\section{NOTES}

It is interesting to note how such conceptualizations extend to empirical reality. In 1986, there was a signboard outside Kanha National Park, that read [Dhaknae ke vastyae - Sher, Cheetah, Bear and Gond aur Baiga Adivasi.] Object of interest include Lion, Chetha, Bear and Gond \& Baiga tribals. The writing was reminiscent of the colonial perspective that categorized people as Blacks and Brown as if they were not Homo sapiens but a species inferior to their own generic form.

\section{REFERENCES}

Borrini - Feyerbend. Grazia: Collaborative Management of Protected Areas: Tailoring the Approach to the Context. International Union for Conservation of Nature Gland, Switzerland (1996).

Bridgewater, P.B. and Shaunesey, G.L.: Austrailia.: (pp. 209228) In: Protecting Nature: Regional Reviews of Protected Areas. J.A. Mcneely, D, Harrision and P. Dingwall (Eds.) Gland, Swtitzerland (1994). 
IUCN. Brosius, P.: Prior Transcripts, divergent paths: Resistance and acquiescence to logging in Sarawak, East Malaysia Comparative Studies in Society and History, 39: 468510 (1997).

Brosius, Peter: Green dots, pink hearts: Displacing politics from the Malaysian rain forest. American Anthro-pologist, 101(1): 367 (1999).

Choudhary, Kameshwar: Development dilemma: Resettlement of Gir maldharis. Economic and Political Weekly, July 22, 2662-2668 (2000).

Conklin, Beth and Graham, Laura: The shifting middle ground: Amazonian Indians and Eco-Politics. Am. Anth. 97: 695710. (1995)

Cronon, William.: Changes in the Land: Indians, Colonists, and the Ecology of New England. Hill and Wang, New York (1983)

Dang, Himraj: Human Conflict in Consrvation: Protected areas, the Indian Experience. Har-Anand Publications, Delhi (1991).

Donnan, Shawn: Feb. 18, p.1. \& 8. Summit of an Aborigine battle for respect. Christian Science Monitor (2000).

Gomez-Pompa, Arturo and Kaus, Andrea: Taming the wilderness myth. Bioscience, 42: 271-279 (1992).

Guha, Ramachandra: The authoritation biologist and the arrognace of humanism: Wildlife conservation in the third world. Ecologist, 27(1): 14-20 (1997).

Guha, Ramachandra: The Unquiet Woods: Ecological Change and Peasant Resistance in the Himalaya. Oxford University Press, Delhi (1997).

Hindu, (The): The Hindu Online. Online. Netscape. 8/3/98. Availabe: - HYPERLINK http://www.hinduonlne http:// www.hinduoline.com/hindu/daily/980802/05/ 0502064.htm (1998).

Holdgate, Martin.: The Green Web: A Union for the Protection of Nature. Earthscan, London (1999).

Huxley, Julian: Memories II. Harper \& Raw Publishers, London (1973).

Nuxley, J.: Man's Place and role in nature. In: New Bottles for New Wine Essays by Huxley. Harper \& Brothers Publishers, New York (1957).

International Union for Conservation of Nature (IUCN): Resolutions of the 12th General Assembly, Kinshasha, Zaire (1975).

International Union for Conservation of Nature (IUCN): Resolution of the 10th General Assembly, New Delhi, India (1969).

International Union for Conservation of Nature (IUCN): Guidelines for Protected Areas Management Categories. CNPPA with assistance from WCMC.IUCN, Gland, Switzerland (1994).

International Union for Conservation of Nature (IUCN): CNPPA in Action: Safeguarding Life on Earth. IUCN Gland, Switzerland (1996).
Kothari, Ashish: Is Joint management of protected areas desireable or possible? pages 17-49. In: People and Protected Areas: Towards Participatory Conservation in India. A. Kothari, N.Singh and S. Suri (Eds.). Sage Publications, New Delhi (1996).

Lewis, Connie (Ed.): Managing Conflicts in Protected Areas. Gland, IUCN. McNeely, Jeffrey. 1994. Forward. pp.xixii In: Managing Conflicts in Protected Areas. C.Lewis. Gland: IUCN (1996).

McNeely, Jeffrey, Harrison, Jeremy and Dingwall, Paul: Introduction: Protected areas in the modern world. pp. 209229. In: Protected Nature: Regional Reviews of Protected Areas. J.A. McNeely, D, Harrison and Dingwall (Eds.). IUCN, Gland, Switzerland (1994).

Merchant, C.: Ecological Revolutions: Nature, Gender and Science in New England. University of North Carolina Press, Chapel Hill, No. Carolina (1989).

Muzaffar, Assadi Economic and Political Weekly. October 5th 1996 Tribals on warpath: Confronting eco-terrorism. pp 2723 (1989).

Narayan, S.: Joint management of Gir National Park. pp. 212225 In: A. Kothari, N. Singh and S. Suri, (Eds.). Sage Publications, New Delhi 1996).

Nathan Dev and Kelkar, Govind: July 28, 2001 Economic and political Weekly Case for local Forest Management, Environment Services, Intenalisation of costs and Markets. xxxvi no-30 pp. 2835-2548 (2001).

Omvedt, Gail: Reinventing Revolution: New Social Movements and the Socialist Tradition in India. M.E. Sharpe, New York (1993).

Poncelet, Eric: A kiss here, a kiss there: Conflict and collaboration in environmental partnerships. Environmental Management, 27(1): 13-26 (2001).

Redford, Kent: The ecologically noble savage. Cultrual Survival, 15(1): 46-48 (1991)

Roosevelt, A. C.: Educating natural scientists about the environment. Practicing Anthroplogy, 17(4): 25-28.

Sarin, Madhu: Who is Going? Who is losing? Gender and equality concerns in Joint Forest Management. Society for Promotion of Wasteland development, Delhi (1996).

Schawrtzman, S., Moriera, A. and Nepstad, D.: Rethinking tropical forest conservation; perils in parks. Conser-vation Biology, 14(5): 1351-1357 (2000).

Scott, James C.: Seein Like A State: How Certain Schemes to Improve the Human Condition Have Failed. Yale University Press, New Haven (1988).

Turner, T.: Indigenous rights, environmental protection and the struggle over forest resources in the Amazon: The case of the Brazilian Kayapo. In: J. Conway, K. Keniston, and L. Marx, (Eds.): Earth, Air, Fire and Water: the Humanities and the Environment. Amherst, University of Massachusetts Press, MA (2000).

World Bank: India Eco-development Project. Information Document, March 22 (1996). 